\title{
Evaluation of the use of vermicompost on the crop production of two varieties of Pak choi (Brassica rapa var. chinensis) and on the soil structure in Suriname
}

\author{
YVONNE INDRANI RAMNARAIN ${ }^{1}$, LYDIA ORI ${ }^{2}$, ABDULLAH ADIL ANSARI ${ }^{3, \bullet}$ \\ ${ }^{1}$ Department of Agricultural Research, Marketing and Processing, Ministry of Agriculture, Animal Husbandry and Fisheries, Paramaribo, Suriname \\ ${ }^{2}$ Anton de Kom University of Suriname, Paramaribo, Suriname \\ ${ }^{3}$ Department of Biology, University of Guyana, Georgetown, Guyana. •email: abdullah.ansari@uog.edu.gy
}

Manuscript received: 6 November 2017. Revision accepted: 21 December 2017.

\begin{abstract}
Ramnarain YI, Ori L, Ansari AA. 2017. Evaluation of the use of vermicompost on the crop production of two varieties of Pak choi (Brassica rapa var. chinensis) and on the soil structure in Suriname. Asian J Agric 1: 73-79. The present research was carried out from January to May 2016 at the Anton de Kom University of Suriname, Paramaribo. The investigation consisted of both field and laboratory work to evaluate the effect of vermicompost on crop production of 2 varieties Brassica rapa var. chinensis, white and green Pak choi, nutrient availability in the soil after the use of vermicompost and nutrient value of the crop. The experiment was carried out (Completely Randomized Block Design) in a greenhouse for six weeks. The treatments were vermicompost (V), cow manure (S), chemical fertilizer $(\mathrm{K})$ and control $(\mathrm{C})$. Plant growth parameters were recorded during the experiment (plant height and number of leaves) and after harvest (root and shoot biomass, leaf area). Nutrient analysis ( $\mathrm{Ca}$ and $\mathrm{Fe}$ ) of Pak choi was also conducted followed by pre- and post-experiment soil analysis ( $\mathrm{pH}, \mathrm{EC}, \mathrm{TOC}, \mathrm{N}, \mathrm{P}, \mathrm{K}$ and $\mathrm{C} / \mathrm{N}$ ratio). The results were collected and analyzed using Sigma Plot 12.0 tools. In the white Pak choi, the number of leaves, root length and weight of fresh plants showed no significant differences among the four treatments using Tukey's test $(\mathrm{P} \leq 0.05)$. In the green Pak choi, the number of leaves and root length showed no significant differences among the four treatments by Tukey's test $(\mathrm{P} \leq 0.05)$. Furthermore, the soil parameters $(\mathrm{pH}, \mathrm{OC}, \mathrm{N})$ did not indicate a significant increase or decrease of the elements in the soil. $\mathrm{P}$ did decrease significantly and the $\mathrm{K}$ increase in the treatment in the soil was not relevant. The evaluation of the use of vermicompost on the crop production of 2 varieties of Pak choi (Brassica rapa var. chinensis) proved that the plants treated with vermicompost had similar results as those treated with cow manure and chemical fertilizer.
\end{abstract}

Keywords: Bio-fertilizer, cow manure nutrients, pak choi, soil, plant-parameters, vegetables, vermicompost

\section{INTRODUCTION}

Vermicompost is a finely divided peat-like material with excellent structure, porosity, aeration, drainage, and moisture holding capacity (Edwards 1988). The input material that is used for vermicomposting decides the nutrient content of the vermicompost. It usually contains higher levels of most of the mineral elements, which are in available forms than the parent material (Edwards and Bohlen 1996). Vermicompost serves as a nutrient rich natural fertilizer, improving the physical, chemical, and biological properties of soil (Ansari and Jaikishun 2011; Nath et al. 2009; Kale 1998) and thus reducing the use of chemical fertilizers (Chanda et al. 2011; Hernandez et al. 2010). It also increases the amount of readily available water, induction of $\mathrm{N}, \mathrm{P}$ and $\mathrm{K}$ exchange, which results in better growth of the plants (Papafotiou et al. 2005; Manivannan et al. 2009). A samba rice cultivation study revealed that the addition of vermicompost had significant positive effects on the soil physical, chemical properties, and plant growth parameters (Tharmaraj et al. 2011). According to Ali et al. (2012), the application of vermicompost increased the soil properties such as organic matter, total nitrogen, phosphorus, potassium, sulfur, zinc, and boron contents; grain and straw yields of rapeseed also increased significantly, when increasing the dose of vermicompost. Therefore, this study focuses on the effect of the application of vermicompost in the cultivation of Brassica rapa var. chinensis, white and green Pak choi and its impact on the soil structure.

\section{MATERIALS AND METHODS}

\section{Experimental design}

This research was carried out from January to May 2016 at the Anton de Kom University of Suriname, Paramaribo. The investigation consisted of a field and laboratory study to evaluate the effect of vermicompost on crop production of 2 varieties Brassica rapa var. chinensis, white and green Pak choi, nutrient availability in the soil after the use of vermicompost and nutrient value of the crop. The field experiment was carried out in a greenhouse for a total of 6 weeks at the Anton de Kom University of Suriname. The experiment was performed using a Completely Randomized Block Design (CRBD) with 3 repetitions for each variety and treatment of vermicompost, cow manure, chemical fertilizer, and control (Figure 1). Each block had an area of $6.0 \mathrm{~m}^{2}\left(4.0 \times 1.50 \mathrm{~m}^{2}\right)$ and each plot in a block had a length of $1 \mathrm{~m}$, width of $0.75 \mathrm{~m}$ and 
height of $0.20 \mathrm{~m}$. Each plot in the block consisted of 12 plants of Pak choi at $25 \times 20 \mathrm{~cm}$ (Figure 2 and Figure 3), with a total of 36 plants per treatment.

\section{Plant material and cultivation}

The white and green Pak choi seeds of the brand TAK II SEED from Japan were used, since this is commonly grown in Suriname. Firstly, the seeds were sown in seed trays $(7 \times 15)$ with potting soil of the brand "Universele potgrond van Egmond" and kept in the greenhouse. The white Pak choi had a germination rate of $94 \%$ and the green Pak choi $98 \%$. After 2 weeks, healthy seedlings were transplanted into the field. A planting depth of approximately $3 \mathrm{~cm}$ was utilized and plant spacing of $25 \times 20 \mathrm{~cm}$. Every day the plants were irrigated, and the harvest took place when the plants were 45 days old. The entire experimental area was managed according to standard practices for nutrient, weed and pest management. The vermicompost, cow manure and chemical fertilizer were applied to the planting hole before transplanting the seedlings into the field. The second amount of fertilizer was applied to the plants in the fourth week. The total amount of added fertilizer per plant is shown in Table 1. According to Sinha et al. (2011), an application of $1-1.5$ tons/acre of vermicompost can be used for leafy vegetables. The same applies for cow manure. For

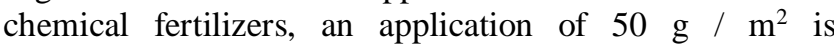
recommendable.

\section{Plant observation and soil analysis}

During the cultivation of Pak choi (Brassica rapa var. chinensis) the following growth parameters were taken weekly until harvest: number of leaves and plant height (cm). Upon maturity, the plants were harvested and preserved for analysis. The following plant growth parameters were measured: root length $(\mathrm{cm})$, shoot biomass fresh (weight in grams)/ dry (at $105^{\circ} \mathrm{C}$ ), root biomass fresh (weight in grams)/ dry (at $105^{\circ} \mathrm{C}$ ) and leaf surface area in $\mathrm{cm}^{2}$. After harvesting, the plants were cut into small pieces and air dried for approximately 48 hours. Afterward, the plant samples were placed in an oven at $60^{\circ} \mathrm{C}$ for 24 hours to dry. According to the laboratory prescription at the soil laboratory of the Anton de Kom University of Suriname, the dried plant tissue was pulverized into particles smaller than $1 \mathrm{~mm}$ and analyzed for nutrient value of Total-Ca (\%) and Total-Fe (ppm). The organic fertilizers (cow manure and vermicompost) and soil samples were subjected to various chemical analyses. Before planting and after harvesting, soil samples were taken from each plot to a depth of $10 \mathrm{~cm}$. The methods described according to the laboratory prescription at the soil laboratory of the Anton de Kom University of Suriname, as mentioned before; that were used to analyze the following parameters: $\mathrm{pH}-\mathrm{H}_{2} \mathrm{O}$, $\mathrm{EC}, \mathrm{TOC}, \mathrm{N}, \mathrm{C} / \mathrm{N}$ ratio, $\mathrm{P}$ and $\mathrm{K}$.

\section{Data analysis}

For the statistical data analysis of the Sigma Plot 12.0 software was used. The data was processed using an Analysis of Variance of Simple Classification and differences between means (one-way ANOVA).
Treatments that were significantly different, were analyzed with Tukey's hoc test. A paired-sample t-test was conducted to compare the control (initial soil) and the experiment (final soil) treatment for different chemical parameters. Significance was set at the 0.05 level.

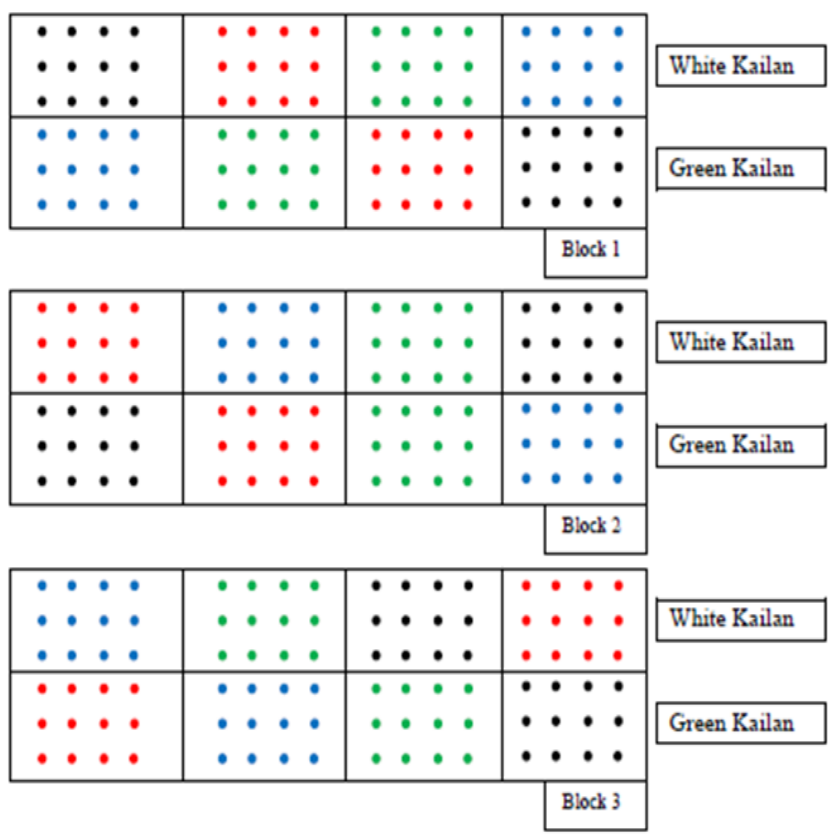

- Control Vermicompost Cow manure Chemical fertilizer

Figure 1. Randomized block design and plot 2016.

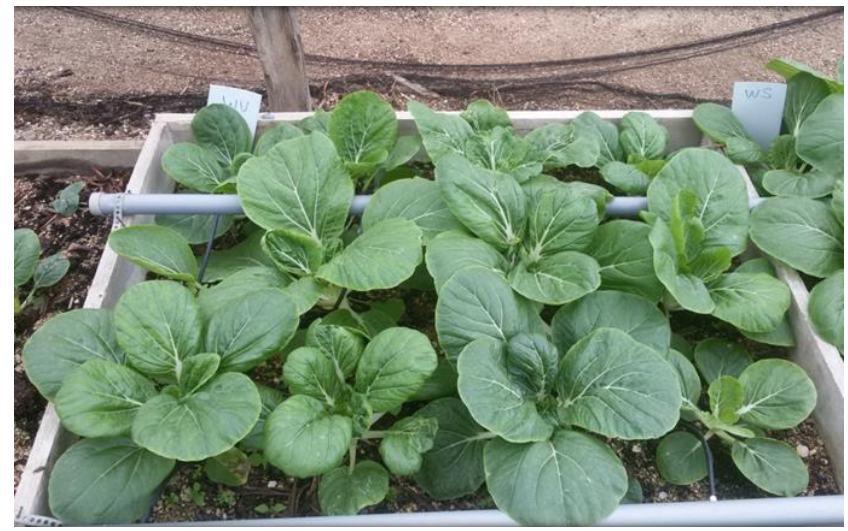

Figure 2. Site view of one plot (white Pak choi) at the greenhouse 2016.

Table 1. Fertilization treatments per plant.

\begin{tabular}{llc}
\hline Symbol & Treatments & $\begin{array}{c}\text { Total amount added } \\
\text { per plant }(\mathbf{g})\end{array}$ \\
\hline $\mathrm{C}$ & Control (soil) & 0 \\
$\mathrm{~S}$ & Cow manure & 100 \\
$\mathrm{~V}$ & Vermicompost & 100 \\
$\mathrm{~K}$ & Fertilizer (12-12-17) & 2 \\
\hline
\end{tabular}




\section{RESULTS AND DISCUSSION}

The research conducted on the use of vermicompost on the productivity of two varieties of Pak choi is highlighted by the impact in terms of plant growth and soil parameters. In Figure 3 the weekly average number of leaves is given and in Figure 4 the weekly average plant height $(\mathrm{cm})$. It can be observed that the number of leaves and plant height did increase weekly until harvesting. There was progressively a greater number of leaves in treatment green Pak choi $[\mathrm{K}]$ followed by white Pak choi [C] and green Pak choi [S] (Figure 3). There was also a progressively greater plant height in treatment white Pak choi [S] followed by white Pak choi $[\mathrm{K}]$ and green Pak choi [V] (Figure 4).

The average values of the plant parameters of both varieties were taken on the $45^{\text {th }}$ day at harvesting, which are shown in Table 2. With reference to cultivation of white Pak choi (Table 2), highest plant height was obtained by WS. The highest weight of fresh root was obtained by WS followed by WK and WV. For leaf area, there was a significant difference between WS and WC, WS and WV, $\mathrm{WS}$ and $\mathrm{WK}(\mathrm{P} \leq 0.05)$. The highest leaf area was obtained by WS followed by WK and WV. With reference to cultivation of green Pak choi (Table 2), the highest plant height was obtained by GV followed by GC and GS. The highest weight of fresh plant was obtained by GC followed by GV and GK. The highest weight of fresh root was obtained by GS followed by GV and GC. The highest leaf area was obtained by GV followed by GC and GS. The results correlate with the works of Pant et al. 2011 and Archana et al. 2012.

According to Amiri Pour et al. (2013), the application of vermicompost to cabbage seedlings indicated that the effects of vermicompost on plant growth and development (leaf area, number of leaves, fresh and dry mass) not only were nutritional, but also hormonal and biochemical ( $\mathrm{Zn}$ and auxin contents). Other studies revealed that the application of vermicompost increased leaf area and biomass in various plants such as radish, marigold, upland cress, Chinese cabbage, strawberry, and tomato (Bachman and Metzger 2008; Singh et al. 2008; Singh et al. 2010; Wang et al. 2010; Warman and Anglopez 2010). As reported by Vennila et al. (2012) vermicompost contains some plant growth stimulating substances, promotes better root growth and nutrient absorption.

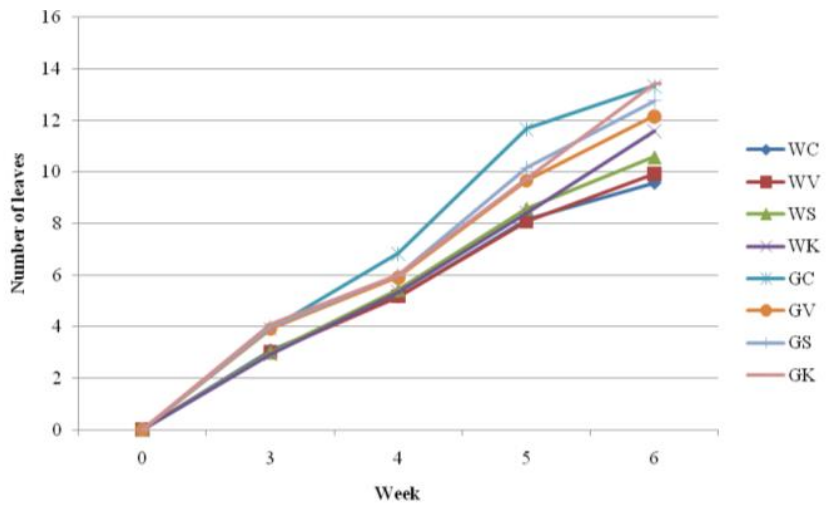

Figure 3. Growth of number of leaves.

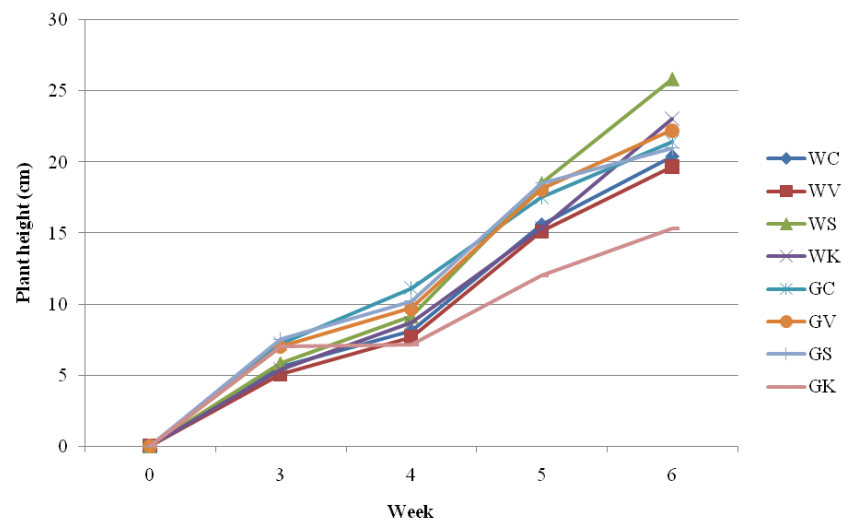

Figure 4. Growth of plant height (cm).

Table 2. Plant parameters of white and green Pak choi (Mean \pm SEM).

\begin{tabular}{|c|c|c|c|c|c|c|}
\hline & Number of leaves & Plant height $(\mathrm{cm})$ & Root length (cm) & $\begin{array}{ll}\begin{array}{l}\text { Weight } \\
\text { plant (g) }\end{array} & \text { fresh } \\
\end{array}$ & $\begin{array}{l}\text { Weight fresh } \\
\text { root }(\mathrm{g})\end{array}$ & Leaf area $\left(\mathrm{cm}^{2}\right)$ \\
\hline \multicolumn{7}{|c|}{ White Pak choi } \\
\hline WC & $10 \pm 0.9 \mathrm{a}$ & $20.40 \pm 1.8 \mathrm{ab}$ & $15 \pm 0.8 \mathrm{a}$ & $109.80 \pm 26.3 \mathrm{a}$ & $8.30 \pm 1.5 \mathrm{~b}$ & $181.80 \pm 17.9 \mathrm{~b}$ \\
\hline WS & $11 \pm 0.3 \mathrm{a}$ & $25.80 \pm 1.2 \mathrm{a}$ & $12.90 \pm 1.0 \mathrm{a}$ & $169.80 \pm 22.6 \mathrm{a}$ & $16.70 \pm 2.0 \mathrm{a}$ & $300.40 \pm 23.7 \mathrm{a}$ \\
\hline WV & $10 \pm 0.3 \mathrm{a}$ & $19.70 \pm 1.5 \mathrm{~b}$ & $12.80 \pm 1.0 \mathrm{a}$ & $108.40 \pm 20.0 \mathrm{a}$ & $9.70 \pm 1.4 \mathrm{~b}$ & $205.30 \pm 18.6 \mathrm{~b}$ \\
\hline WK & $12 \pm 0.8 \mathrm{a}$ & $23 \pm 1.1 \mathrm{ab}$ & $13.80 \pm 1.1 \mathrm{a}$ & $115.30 \pm 14.9 \mathrm{a}$ & $10.20 \pm 1.2 \mathrm{~b}$ & $207.10 \pm 17.0 \mathrm{~b}$ \\
\hline \multicolumn{7}{|c|}{ Green Pak choi } \\
\hline GC & $13 \pm 0.7 \mathrm{a}$ & $21.40 \pm 0.8 \mathrm{a}$ & $13.50 \pm 0.7 \mathrm{a}$ & $117.10 \pm 13.6 \mathrm{a}$ & $6.70 \pm 0.6 \mathrm{a}$ & $141.80 \pm 11.9 \mathrm{a}$ \\
\hline GS & $13 \pm 0.9 \mathrm{a}$ & $21.00 \pm 1.1 \mathrm{a}$ & $11.40 \pm 0.8 \mathrm{a}$ & $93.30 \pm 14.7 \mathrm{ab}$ & $9.30 \pm 2.0 \mathrm{a}$ & $111.60 \pm 10.0 \mathrm{ab}$ \\
\hline GV & $12 \pm 0.7 \mathrm{a}$ & $22.30 \pm 1.2 \mathrm{a}$ & $14.00 \pm 0.9 \mathrm{a}$ & $110.60 \pm 18.2 \mathrm{a}$ & $8.40 \pm 1.1 \mathrm{a}$ & $156.00 \pm 15.8 \mathrm{a}$ \\
\hline GK & $13 \pm 0.8 \mathrm{a}$ & $15.30 \pm 1.2 \mathrm{~b}$ & $11.00 \pm 0.9 \mathrm{a}$ & $46.40 \pm 9.0 \mathrm{~b}$ & $3.10 \pm 0.8 \mathrm{~b}$ & $71.10 \pm 6.3 \mathrm{~b}$ \\
\hline
\end{tabular}

Note: WC: White Control; WS: White Cow manure; WV: White Vermicompost; WK: White Chemical Fertilizer; GC: Green Control; GS: Green Cow manure; GV: Green Vermicompost; GK: Green Chemical Fertilizer. *Values followed by different letters are significantly different at $\mathrm{P} \leq 0.05$ according to Tukey's multiple range test (Tukey's test) 
Earlier studies have reported a positive effect of vermicompost application on growth and productivity of cereals and legumes (Hameeda et al. 2007; Ansari and Jaikishun 2011; Fritz et al. 2012), ornamental and flowering plants (Atiyeh et al.2002; Marfá et al. 2002; Arancon et al. 2008; Chamani 2008; Lazcano and Dominguez 2010), vegetables (Atiyeh et al. 2000; Ansari 2008b; Peyvast et al. 2008; Suthar 2009; Ansari and Sukhraj 2010). Vadiraj et al. (1998) reported that application of vermicompost produced herbage yields of coriander cultivars were comparable to those obtained with chemical fertilizers, which agree with the findings of this current study, indicating that the usage of any artificial chemical input is not needed.

Nutrients in plants are an essential component for the nutritive value in diet and are indication of good plant productivity. Table 3 illustrates an overview of the nutrient value in white and green Pak choi. With reference to cultivation of white Pak choi, the nutrient analysis indicated that the highest T-Ca was observed in WK followed by WS and WC. With reference to cultivation of green Pak choi, the nutrient analysis indicated that the highest T-Fe was observed in GC followed by GK and GV.

The concentrations of total $\mathrm{Ca}$ in both varieties of Pak choi were in range of sufficient or normal concentrations (Table 4) of macroelements that should occur in mature leaf tissue, which is between $1-4 \%$. The concentrations of total $\mathrm{Fe}$ in both varieties of Pak choi were in range of sufficient or normal concentrations of microelements that should occur in mature leaf tissue, which is between 100 500 ppm (Munson 1998).

Table 5 provides an overview of the cow manure, vermicompost and soil measured parameters before and after harvesting of the field experiment "cultivation of white and green Pak choi". The results of the chemical analysis of cow manure and vermicompost are also shown. For each analysis, 3 samples were taken to determine the nutrient value. The $\mathrm{pH}-\mathrm{H}_{2} \mathrm{O}$ in the vermicompost was $6.60 \pm 0.00$ and in the cow manure $6.03 \pm 0.03$. The soluble salt concentrations (measured as Electric conductivity) in the resulting vermicompost and cow manure were respectively $7200 \pm 180 \mu \mathrm{S} / \mathrm{cm}$ and $8367 \pm 300 \mu \mathrm{S} / \mathrm{cm}$, indicating a lower salinity in the vermicompost compared to the cow manure. The total organic carbon was $23.20 \pm 0.59 \%$ in the vermicompost and $17.69 \pm 0.72 \%$ in the cow manure. The total nitrogen was $1.60 \pm 0.04 \%$ in the vermicompost and $1.48 \pm 0.05 \%$ in the cow manure. The $\mathrm{C} / \mathrm{N}$ ratio in the vermicompost and cow manure was as followed 15:1 and $12: 1$. Total phosphorus was $8745 \pm 604.26 \mathrm{ppm}$ in the vermicompost and $9818 \pm 195.73 \mathrm{ppm}$ in the cow manure. The total potassium was $7030 \pm 186.48 \mathrm{ppm}$ in the vermicompost and $8255 \pm 473.30 \mathrm{ppm}$ in cow manure. Vermicompost contains essential nutrients, which were within the limits as reported by earlier researchers (Ismail 1997; Ansari and Sukhraj 2010; Ansari et al. 2016).

Soil $\mathrm{pH}$ did not have a notable increase or decrease for all the treatments (Table 6). Soil pH is one of the most important soil properties that affect the availability of nutrients. Macronutrients tend to be less available in soils with low $\mathrm{pH}$ and micronutrients tend to be less available in soils with high $\mathrm{pH}$ (Ansari and Jaikishun 2011). According to Krogh (2005), worm cast and composts are considered to have a positive effect on soil by helping to balance the $\mathrm{pH}$, retain moisture, improve drainage, and control pathogens. Vermicompost improves the $\mathrm{pH}$ of soil and makes the nutrient available for the crop yield (Srikanth et al. 2000).

Soil EC did increase in all the samples though not significantly, except for WS which indicated a relevant increase (Table 7). According to Atiyeh et al. (2002), the electrical conductivity of vermicompost depends on the raw materials used for vermicomposting and their ion concentration.

Organic carbon did not increase or decrease significantly in the soil (Table 8). According to Ansari and Jaikishun (2011), vermicompost are rich in organic carbon content and can release these into the soil very slowly and steadily, enabling the plants to absorb the available nutrients (Lalitha et al. 2000; Ansari 2008a; b).

Nitrogen did not increase or decrease notably in the soil (Table 9). The presence of nitrogen fixing bacteria in the vermicompost plays a great role in increasing the nitrogen content of the soil and mineralization (Lalitha et al. 2000; Debosz et al. 2002; Arancon et al. 2006; Ansari 2008a; b).

Phosphorous did decrease notably in the treatments WV, GC, and GS (Table 10). According to Erich et al. (2002), the application of vermicompost increases the bioavailability of phosphorus in the soil affecting plant growth in potato cropping.

Table 3. Nutrient value in Pak choi varieties after harvesting (Mean \pm SEM).

\begin{tabular}{lll}
\hline Parameter & T-Ca (\%) & T-Fe (ppm) \\
White Pak choi & & \\
WC: White Control & $1.94 \pm 0.08 \mathrm{a}$ & $114 \pm 6.85 \mathrm{a}$ \\
WS: White Cow manure & $1.94 \pm 0.04 \mathrm{a}$ & $122 \pm 5.36 \mathrm{a}$ \\
WV: White Vermicompost & $1.67 \pm 0.03 \mathrm{~b}$ & $123 \pm 4.07 \mathrm{a}$ \\
WK: White Chemical Fertilizer & $2.00 \pm 0.02 \mathrm{a}$ & $112 \pm 6.42 \mathrm{a}$ \\
& & \\
Green Pak choi & & \\
GC: Green Control & $2.22 \pm 0.06 \mathrm{a}$ & $146 \pm 8.71 \mathrm{a}$ \\
GS: Green Cow manure & $2.12 \pm 0.05 \mathrm{a}$ & $107 \pm 6.32 \mathrm{~b}$ \\
GV: Green Vermicompost & $2.14 \pm 0.06 \mathrm{a}$ & $107 \pm 2.83 \mathrm{~b}$ \\
GK: Green Chemical Fertilizer & $2.27 \pm 0.04 \mathrm{a}$ & $108 \pm 4.54 \mathrm{~b}$ \\
\hline
\end{tabular}

Note: *Values followed by different letters are significantly different at $\mathrm{P} \leq 0.05$ according to Tukey's multiple range test (Tukey's test).

Table 4. Concentration or ranges of the major elements and micronutrients in mature leaf tissue generalized as deficient, sufficient, or excessive for various plant species (Munson 1998).

\begin{tabular}{llll}
\hline $\begin{array}{l}\text { Essential } \\
\text { elements }\end{array}$ & $\begin{array}{l}\text { \% } \\
\text { Deficient }\end{array}$ & $\begin{array}{l}\text { \% Sufficient or } \\
\text { normal }\end{array}$ & $\begin{array}{l}\text { \% Excessive } \\
\text { or toxic }\end{array}$ \\
\hline $\begin{array}{l}\text { Major elements } \\
\text { Calcium (Ca) }\end{array}$ & $<0.50$ & $1.00-4.00$ & $>5.00$ \\
& & & \\
$\begin{array}{l}\text { Micronutrients } \\
\text { Iron (Fe) }\end{array}$ & $\begin{array}{l}\text { ppm } \\
<50\end{array}$ & $\begin{array}{l}\text { ppm } \\
100-500\end{array}$ & $\begin{array}{l}\text { ppm } \\
>500\end{array}$ \\
\hline
\end{tabular}


Table 5. Cow manure, vermicompost and soil parameters (Mean \pm SEM).

\begin{tabular}{|c|c|c|c|c|c|c|c|}
\hline Parameter & pH- $\mathrm{H}_{2} \mathrm{O}$ & $\mathrm{EC}(\mu \mathrm{S} / \mathrm{cm})$ & $\begin{array}{c}\text { TOC } \\
(\%)\end{array}$ & $\begin{array}{l}\text { TN } \\
(\%) \\
\end{array}$ & $\begin{array}{l}\mathrm{C} / \mathrm{N} \\
\text { ratio }\end{array}$ & TP (ppm) & TK (ppm) \\
\hline Cow manure & $6.03 \pm 0.03$ & $8367 \pm 300$ & $17.69 \pm 0.72$ & $1.48 \pm 0.05$ & 12: 1 & $9818 \pm 195.73$ & $8255 \pm 473.30$ \\
\hline Vermicompost & $6.60 \pm 0.00$ & $7200 \pm 180$ & $23.20 \pm 0.59$ & $1.60 \pm 0.04$ & 15: 1 & $8745 \pm 604.26$ & $7030 \pm 186.48$ \\
\hline \multicolumn{8}{|l|}{ Before } \\
\hline Soil & $7.65 \pm 0.35$ & $369 \pm 36.50$ & $3.87 \pm 0.76$ & $0.25 \pm 0.04$ & 16: 1 & $2050 \pm 127.75$ & $792 \pm 34.26$ \\
\hline \multicolumn{8}{|l|}{ After } \\
\hline WC & $7.85 \pm 0.05$ & $1612 \pm 498$ & $4.52 \pm 1.44$ & $0.25 \pm 0.12$ & 18: 1 & $2813 \pm 2717$ & $1011 \pm 410$ \\
\hline WS & $7.55 \pm 0.05$ & $1465 \pm 114$ & $4.41 \pm 0.40$ & $0.31 \pm 0.06$ & $14: 1$ & $648 \pm 10$ & $853 \pm 35$ \\
\hline WV & $7.60 \pm 0.00$ & $1525 \pm 318$ & $3.82 \pm 0.59$ & $0.25 \pm 0.0$ & 15: 1 & $276 \pm 77$ & $725 \pm 25$ \\
\hline WK & $7.95 \pm 0.15$ & $1202 \pm 350$ & $2.95 \pm 0.09$ & $0.17 \pm 0.0$ & 17: 1 & $851 \pm 623$ & $834 \pm 296$ \\
\hline GC & $7.65 \pm 0.35$ & $1314 \pm 465$ & $4.52 \pm 1.62$ & $0.29 \pm 0.11$ & 16: 1 & $490 \pm 186$ & $685 \pm 15$ \\
\hline GS & $7.60 \pm 0.10$ & $1509 \pm 711$ & $4.35 \pm 0.11$ & $0.32 \pm 0.04$ & 14: 1 & $1049 \pm 154$ & $996 \pm 64$ \\
\hline GV & $7.60 \pm 0.00$ & $1164 \pm 379$ & $5.99 \pm 0.42$ & $0.37 \pm 0.03$ & 16: 1 & $3228 \pm 2733$ & $1103 \pm 408$ \\
\hline GK & $7.65 \pm 0.05$ & $2045 \pm 246$ & $4.89 \pm 0.96$ & $0.30 \pm 0.09$ & 16: 1 & $2972 \pm 2675$ & $1046 \pm 481$ \\
\hline
\end{tabular}

Note: WC: White Control; WS: White Cow manure; WV: White Vermicompost; WK: White Chemical Fertilizer; GC: Green Control; GS: Green Cow manure; GV: Green Vermicompost; GK: Green Chemical Fertilizer; TOC: Total Organic Carbon; TN: Total-N; TP: Total-P; TK: Total-K

Table 6. Soil $\mathrm{pH}($ Mean \pm SEM).

Table 9. Total Nitrogen (\%) (Mean \pm SEM).

\begin{tabular}{|c|c|c|c|c|c|c|c|}
\hline Treatment & Initial soil & Final soil & Increase in pH & Treatment & Initial soil & Final soil & Increase in $\mathbf{N}(\%)$ \\
\hline WC & $7.65 \pm 0.35$ & $7.85 \pm 0.05$ & 0.20 & WC & $0.25 \pm 0.04$ & $0.25 \pm 0.12$ & 0.00 \\
\hline WS & $7.65 \pm 0.35$ & $7.55 \pm 0.05$ & -0.10 & WS & $0.25 \pm 0.04$ & $0.31 \pm 0.06$ & 0.06 \\
\hline WV & $7.65 \pm 0.35$ & $7.60 \pm 0.00$ & -0.05 & WV & $0.25 \pm 0.04$ & $0.25 \pm 0.00$ & 0.00 \\
\hline WK & $7.65 \pm 0.35$ & $7.95 \pm 0.15$ & 0.30 & WK & $0.25 \pm 0.04$ & $0.17 \pm 0.0$ & -0.08 \\
\hline GC & $7.65 \pm 0.35$ & $7.65 \pm 0.35$ & 0.00 & GC & $0.25 \pm 0.04$ & $0.29 \pm 0.11$ & 0.04 \\
\hline GS & $7.65 \pm 0.35$ & $7.60 \pm 0.10$ & -0.05 & GS & $0.25 \pm 0.04$ & $0.32 \pm 0.04$ & 0.07 \\
\hline $\mathrm{GV}$ & $7.65 \pm 0.35$ & $7.60 \pm 0.00$ & -0.05 & GV & $0.25 \pm 0.04$ & $0.37 \pm 0.03$ & 0.12 \\
\hline GK & $7.65 \pm 0.35$ & $7.65 \pm 0.05$ & 0.00 & GK & $0.25 \pm 0.04$ & $0.30 \pm 0.09$ & 0.05 \\
\hline
\end{tabular}

Note: Confidence level 95\%; - indicates decrease

Note: Confidence level 95\%; - indicates decrease

Table 7. Soil EC $(\mu \mathrm{S} / \mathrm{cm})($ Mean $\pm \mathrm{SEM})$.

Table 10. Total phosphorous (ppm) (Mean \pm SEM).

\begin{tabular}{|c|c|c|c|c|c|c|c|c|}
\hline Treatment & Initial soil & Final soil & $\begin{array}{c}\text { Increase in EC } \\
(\mu \mathrm{S} / \mathrm{cm})\end{array}$ & Treatment & Initial soil & Final soil & $\begin{array}{c}\text { Increase in } \\
\mathbf{P}(\mathbf{p p m})\end{array}$ & t-test \\
\hline WC & $369 \pm 36.50$ & $1612 \pm 498$ & 1243 & WC & $2050 \pm 127.75$ & $2813 \pm 2717$ & 763 & NS \\
\hline WS & $369 \pm 36.50$ & $1465 \pm 114$ & 1096 & WS & $2050 \pm 127.75$ & $648 \pm 10$ & -1402 & NS \\
\hline WV & $369 \pm 36.50$ & $1525 \pm 318$ & 1156 & WV & $2050 \pm 127.75$ & $276 \pm 77$ & -1774 & $*$ \\
\hline WK & $369 \pm 36.50$ & $1202 \pm 350$ & 833 & WK & $2050 \pm 127.75$ & $851 \pm 623$ & -1199 & NS \\
\hline GC & $369 \pm 36.50$ & $1314 \pm 465$ & 945 & GC & $2050 \pm 127.75$ & $490 \pm 186$ & -1560 & $*$ \\
\hline GS & $369 \pm 36.50$ & $1509 \pm 711$ & 1140 & GS & $2050 \pm 127.75$ & $1049 \pm 154$ & -1001 & * \\
\hline GV & $369 \pm 36.50$ & $1164 \pm 379$ & 795 & GV & $2050 \pm 127.75$ & $3228 \pm 2733$ & 1178 & NS \\
\hline GK & $369 \pm 36.50$ & $2045 \pm 246$ & 1676 & GK & $2050 \pm 127.75$ & $2972 \pm 2675$ & 922 & NS \\
\hline
\end{tabular}

Note: Confidence level 95\%; - indicates decrease

Note: Confidence level 95\%; - indicates decrease; *= significant; $\mathrm{NS}=$ not significant

Table 8. Total Organic carbon (\%) (Mean \pm SEM).

Table 11. Total Potassium (ppm) (Mean \pm SEM).

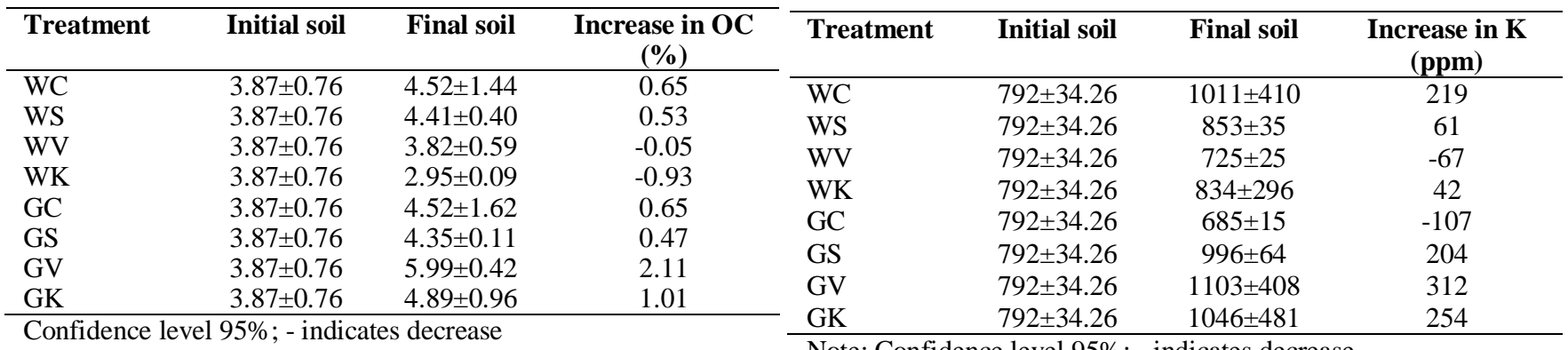

Note: Confidence level 95\%; - indicates decrease 
Potassium increase in the treatments in the soil was not relevant, although there was a decrease in WV and GC (Table 11). The increase in potassium uptake by vermicompost application may be due to the enhancement in potassium availability by shifting the equilibrium among the forms of potassium from relatively exchangeable potassium to soluble potassium forms in the soil (Bhasker et al. 1992).

In conclusion, the evaluation of the use of vermicompost on the crop production of 2 varieties of Pak choi (Brassica rapa var. chinensis) proved that the plants treated with vermicompost had similar results as those treated with cow manure and chemical fertilizer. The plant nutrient concentrations of $\mathrm{Ca}$ and $\mathrm{Fe}$ were in range of sufficient or normal concentrations of macro and microelements that should occur in mature leaf tissue. The soil parameters $(\mathrm{pH}, \mathrm{OC}, \mathrm{N})$ did not indicate a significant increase or decrease of the elements in the soil. $\mathrm{P}$ did decrease significantly and $\mathrm{K}$ increase in the treatments in the soil was not relevant. This research should be continued to evaluate the use of vermicompost in the production of other vegetables.

\section{REFERENCES}

Ali M, Hossain M, Rahman M, Islam M. 2012. Effect of vermicompost on growth, yield, chemical composition, and Oil content of rapeseed (var. SAU SHARISHA-1). J Experimental Biol Sci 3 (2): 91-96.

Amiri Pour A, Ladan Moghadam AR, Oraghi Ardebili Z. 2013. The effects of different levels of vermicompost on the growth and physiology of cabbage seedlings. Intl Res J Appl Basic Sci 4 (9): 2726-2729.

Ansari A, Jaikishun S. 2011. Vermicomposting of sugarcane bagasse and rice straw and its impact on the cultivation of Phaseolus vulgaris L. in Guyana, South America. J Agric Technol 7 (2): 225-234.

Ansari A. 2008a. Effect of vermicompost and vermiwash on the productivity of spinach (Spinacia oleracea), onion (Allium cepa) and potato (Solanum tuberosum). World J Agric Sci 4 (5): 554-557.

Ansari A. 2008b. Effect of Vermicompost on the Productivity of Potato (Solanum tuberosum), Spinach (Spinacia oleracea) and Turnip (Brassica campestris). World J Agric Sci 4 (3): 333-336.

Ansari A, Sukhraj K. 2010. Effect of vermiwash and vermicompost on soil parameters and productivity of okra (Abelmoschus esculentus) in Guyana. African J Agric Res 5 (14): 1794-1798.

Ansari A, Jaikishun S, Islam S K, Kuri K F, Nandwani D. 2016. Principles of vermitechnology in sustainable organic farming with special reference to Bangladesh. In: Nandwani D (ed.) Organic Farming for Sustainable Agriculture. Springer International Publishing, Switzerland.

Arancon NQ, Edwards CA, Babenko A, Cannon J, Galvis P, Metzger JD. 2008. Influences of vermicomposts, produced by earthworms and microorganisms from cattle manure, food waste and paper waste, on the germination, growth, and flowering of petunias in the greenhouse. Appl Soil Ecol 39: 91-99.

Arancon NQ, Edwards CA, Bierman P. 2006. Influence of vermicompost on field strawberries: Effects on soil microbiological and chemical properties. Bioresour Technol 97: 831-840.

Atiyeh RM, Arancon NQ, Edwards CA, Metzger JD. 2002. The influence of earthworm processed pig manure on the growth and productivity of marigolds. Bioresour Technol 81: 103-108

Atiyeh RM, Dominguez J, Sobler S, Edwards CA. 2000. Changes in biochemical properties of cow manure during processing by earthworms (Eisenia andrei) and the effects on seedling growth Pedobiologia, 44: 709-724.

Bachman GR, Metzger JD. 2008. Growth of bedding plants in commercial potting substrate amended with vermicompost. Bioresour Technol 99 (8): $3155-3161$.
Bhasker A, Macgregor AN, Kirkman JH. 1992. Influence of soil ingestion by earthworms on the availability of potassium in soil: An incubation experiment. Biol Fertil Soils 14: 300-303.

Chamani E, Joyce DC, Reihanytabar A. 2008. Vermicompost effects on the growth and flowering of Petunia hybrida 'Dream Neon Rose'. American-Eurasian J Agric Environ Sci 3 (3): 506-512

Chanda, G K, Bhunia G, Chakraborty SK. 2011. The effect of vermicompost and other fertilizers on cultivation of tomato plants. J Hortic For 3 (2): 42-45.

Debosz K, Petersen SO, Kure LK, Ambus P. 2002. Evaluating effects of sewage sludge and household compost on soil physical, chemical and microbiological properties. Appl Soil Ecol 3: 237-248

Edwards CA. 1988. Breakdown of animal, vegetable, and industrial organic wastes by earthworms. Agric Ecosyst Environ 24; 21-31.

Edwards CA, Bohlen PJ. 1996. Biology and Ecology of Earthworms. 3rd Eds. Chapman and Hall, London.

Erich MS, Fitzgerald CB, Porter GA. 2002. The effect of organic amendments on phosphorus chemistry in a potato cropping system. Agric Ecosyst Environ 88: 79-88.

Fritz JI, Franke-Whittle IH, Haindl S, Insam H, Braun R. 2012. Microbiological community analysis of vermicompost tea and its influence on the growth of vegetables and cereals. Canadian J Microbiol 58 (7): 836-847.

Hameeda B, Harini G, Rupela OP, Reddy G. 2007. Effect of composts or vermicomposts on sorghum growth and mycorrhizal colonization. African J Biotechnol 6 (1): 9-12.

Hernández A, Castillo H, Ojeda D, Arras A, Lopez J, Sanchez E. 2010. Effect of vermicompost and compost on lettuce production. Chilean J Agric Res 70 (4): 583-589.

Ismail SA. 1997. Vermicology: The Biology of Earthworms. Orient Longman Press, Hyderabad.

Kale RD. 1998. Earthworm Cinderella of Organic Farming. Prism Book. Pvt Ltd, Bangalore, India.

Krogh D. 2005. Biology: A guide to the Natural World. $3^{\text {rd }}$ ed. PrenticeHall, New Jersey.

Lalitha R, Fathima K, Ismail S.A. 2000. Impact of biopesticides and microbial fertilizers on productivity and growth of Abelmoschus esculentus. Vasundhara The Earth 1 (2): 4-9.

Lazcano C, Dominguez J. 2010. Effects of vermicompost as a potting amendment of two commercially-grown ornamental plant species. Spanish J Agricultural Research, 8 (4): 1260-1270.

Manivannan S, Balamurugan M, Parthasarathi K, Gunasekaran G, Ranganathan LS. 2009. Effect of vermicompost on soil fertility and crop productivity-beans (Phaseolus vulgaris). J Environ Biol 30: 275 281.

Marfá O, Lemaire F, Caceres R, Giuffrida F, Guerin V. 2002. Relationships between growing media fertility, percolate composition and fertigation strategy in peat-substitute substrates used for growing ornamental shrubs. Scientia Horticulturae 94: 309-321.

Munson R. 1998. Principles of plant analysis. In: Kalra Y. (ed.) Handbook of Reference Methods for Plant Analysis, Soil and Plant Analysis Council, Inc. CRC Press Taylor \& Francis Group LLC. Boca Raton, FL.

Nath G, Singh K, Sing D. 2009. Chemical Analysis of Vermicomposts / Vermiwash of Different Combinations of Animal, Agro and Kitchen Wastes. Austr J Basic Appl Sci 3 (4): 3671-3676.

Papafotiou M, Kargas G, Lytra I. 2005. Olive mill waste compost as a growth medium component for foliage potted plants. Hortic Sci 40: 1746-1750.

Peyvast Gh, Olfati JA, Madeni S, Forghani A, Samizadeh H. 2008. Vermicompost as a Soil Supplement to Improve Growth and Yield of Parsley. Intl J Veget Sci 14 (1): 82-92.

Singh R, Gupta RK, Patil RT, Sharma RR, Asrey R, Kumar A, Jangra KK. 2010. Sequential foliar application of vermicompost leachates improves marketable fruit yield and quality of strawberry (Fragaria $x$ ananassa Duch.). Scientia Horticulturae, 124 (1): 34-39.

Singh R, Sharma RR, Kumar S, Patil RT. 2008. Vermicompost substitution influences growth, physiological disorders, fruit yield and quality of strawberry (Fragaria $x$ ananassa Duch.). Bioresour Technol 99: 8507-8511.

Sinha K, Valani D, Soni B, Chandran V. 2011. Earthworm vermicompost. A sustainable alternative to chemical fertilizers for organic farming. Agriculture issues and policies. Nova Sci Publishers, Inc, New York.

Srikanth K, Srinivasamurthy CA, Siddaramappa R, Ramakrishnaparama VR. 2000. Direct and residual effect of enriched compost, FYM, 
vermicompost and fertilizers on properties of an Alfisol. J Ind Soc Soil Sci 48: 496-499.

Suthar S. 2009. Impact of vermicompost and composted farmyard manure on growth and yield of garlic (Allium sativum L.) field crop. Intl J Plant Prod 3 (1): 27-38

Tharmaraj K, Ganesh P, Kolanjinathan K, Suresh Kumar R, Anandan A. 2011. Influence of vermicompost and vermiwash on physicochemical properties of rice cultivated soil. Curr Bot 2 (3): 18-21.

Vadiraj BA, Siddagangaiah D, Narayna Potty S. 1998. Response of coriander (Coriandrum sativum L.) cultivars to graded levels of vermicompost. J Spices Aromat Crops 7 (2): 141-143.
Vennila C, Jayanthi C, Sankaran V.M. 2012. Vermicompost on crop production - A Review. Agric Rev 33 (3): 265-270.

Wang D, Shi Q, Wang X, WeiM, HuJ, LiuJ, Yang F. 2010.Influence of cow manure vermicompost on the growth, metabolite contents, and antioxidant activities of Chinese cabbage (Brassica campestris ssp. chinensis). Biol Fert Soils 46 (7): 689-696.

Warman PR, Anglopez MJ. 2010. Vermicompost derived from different feedstocks as a plant growth medium. Bioresour Technol 101 (12): 4479-4483. 